\title{
Carrying capacity assessment in tourism: the case of Northern Sporades islands
}

\author{
D. G. Prokopiou ${ }^{1}$, B. S. Tselentis ${ }^{1} \&$ M. Toanoglou ${ }^{2}$ \\ ${ }^{1}$ Department of Maritime Studies, University of Piraeus, Greece \\ ${ }^{2}$ Euroxenia, Hotel Management and Tourism Consulting, Rhodes, Greece
}

\begin{abstract}
Tourism is the main economic activity in Greece. Carrying capacity assessment is now important for the sustainable development of tourist destinations as it is also an antiquated approach to managing the impacts of the tourist industry on the environment.

Northern Sporades consists of four islands; accommodation comprises of over 30,000 beds and more than 400,000 visitors per year, differing by their development limits. The environment, both natural and manmade, characterizes the tourist product for the islands.

For the Greek Islands, the environment plays a leading role in the tourist industry. It is the purpose of this paper to apply the principles of carrying capacity assessment to Northern Sporades islands in order to state the tourism business opportunities. In this study we have used environmental indexes to estimate the impact of development on the environment, in order to suggest a sustainable tourism development proposal.

Keywords: tourism carrying capacity, tourism and environment, tourism development, destinations and environment.
\end{abstract}

\section{Introduction}

The Northern Sporades islands are an archipelago along the east coast of Greece, south of Pilion Mountain and Volos city and northeast of the island of Euboea, in the middle of the Aegean Sea. It consists of 24 islands, four of which are permanently inhabited: The inhabited islands are Alonnisos, Skiathos, Skopelos and Skyros. Old Trickeri is a small island close to Pilion Mountain and Skiathos. 
The biggest island is Allonisos whereas Skiathos is the most populated. These islands are famous for their beautiful sandy beaches and also for the pine trees which are everywhere.

Table 1: General statistics and tourism capacity.

\begin{tabular}{|c|c|c|c|c|c|c|}
\hline & Population & Area (sq. km) & Density & Hotel beds & $\begin{array}{c}\text { Beds (other } \\
\text { lodgings) }\end{array}$ & $\begin{array}{c}\text { Total tourism } \\
\text { capacity }\end{array}$ \\
\hline ALLONISOS & 2700 & 129,61 & 20,83 & & & 3442 \\
\hline SKIATHOS & 6160 & 49,898 & 123,45 & 6799 & 6664 & 14562 \\
\hline SKOPELOS & 4696 & 96,299 & 48,76 & 2574 & 4940 & 7514 \\
\hline TRIKERI & 87 & 2,5 & 34,80 & 10 & 51 & 61 \\
\hline SKYROS & 2602 & 223,1 & 11,66 & 605 & 1041 & 1646 \\
\hline
\end{tabular}

\subsection{Skiathos}

Skiathos is the most cosmopolitan island of the Northern Sporades. It is an island with a unique, rich environment and nature, hospitable people, and great history. In 1807, the first Greek flag was erected on the island at the Convent of the Annunciation. The first Greek naval fleet was built in Skiathos in the revolution of 1821 and the greatest Greek novelist, Alex Papadiamantis, came from there.

\subsection{Scopelos}

Skopelos is an island in the middle of the Aegean Sea near Pelion. It has an area of $96 \mathrm{~km}^{2}$ and 6,000 inhabitants. Its unique environment is the main tourist attraction; Skopelos is one of the greenest islands in Greece. The architectural character of the island is well maintained and the tradition of the island is rich. Music and other traditions are still maintained and are frequently presented. Remarkable are the local products of the island, such as wine, almonds and sweet plum. Some years ago, the "Skopelos Photographic Festival" an international event for creative photography was held there although this is not the case now.

\subsection{Allonisos}

Allonisos is an island close to Skopelos. The village of Alonnisos is located in the southern part of the island. It is locally known as Chora. The main port of the island is located in the southeast and is called Patitiri.

The coasts of Allonisos are inhabited by the Mediterranean monk seal (Monachus monachus); a pinniped belonging to the Phocidae family. There are 450-500 individuals of these endangered mammals and for their protection, a sea park has been established, organized by a specialized organization for the seals settled in Allonisos. 


\subsection{Skyros}

Skyros is an island in the south Sporades, an archipelago in the Aegean Sea. It is part of the regional unit of Euboea. It has nice beaches, and a human environment with a unique tradition.

\subsection{Trikeri}

Trikeri is free of any traffic. Following the coastal paths, it is possible to walk around the island in a few hours. The environment of Trikeri is virgin.

\section{Tourism}

\subsection{Skiathos}

Tourist development of the island started in the early 1980s; the centre of the island, Skiathos town, being the main settled district. After the 1990s, the whole island was developed.

Table 2: $\quad$ Total passenger arrivals in Skiathos port and airport.

\begin{tabular}{|l|c|c|c|c|c|}
\hline \multicolumn{2}{|c|}{$\begin{array}{c}\text { Passenger arrivals in Skiathos Port } \\
\text { (from ferries and hydrofoils) }\end{array}$} & \multicolumn{3}{c|}{$\begin{array}{c}\text { Skiathos Airport } \\
\text { passenger arrivals }\end{array}$} \\
\hline & HYDROFOILS & FERRIES & & DOMESTIC & ABROAD \\
\hline January & 1890 & 2370 & 1994 & 12,224 & 119,301 \\
\hline February & 2359 & 1591 & 1995 & 11,644 & 110,706 \\
\hline March & 4562 & 2741 & 1996 & 11,571 & 91,119 \\
\hline April & 6453 & 7362 & 1997 & 12,774 & 94,156 \\
\hline May & 8377 & 7456 & 1998 & 12,514 & 110,723 \\
\hline June & 14,748 & 14,305 & 1999 & 9,775 & 119,351 \\
\hline July & 22,849 & 32,563 & 2000 & 9,723 & 127,962 \\
\hline August & 25,793 & 39,497 & 2001 & 6,607 & 152,115 \\
\hline September & 12,926 & 8971 & 2002 & 5,177 & 155,897 \\
\hline October & 4660 & 3868 & 2003 & 7,029 & 143,717 \\
\hline November & 2738 & 2963 & 2004 & 8,124 & 118,431 \\
\hline December & 2620 & 2401 & 2005 & 7,728 & 113,659 \\
\hline
\end{tabular}

In 1993, the island was in danger of losing its identity; in Skiathos town everywhere there were ugly buildings. After 1983, the Act for the Architectural Environment for Sporades Island and Pilion changed the architectural character of the new buildings as the traditional buildings were protected. The town was renovated. Skiathos airport opened in 1978 but in 1982 arrivals had not increased by more than 20,000 .

Skiathos Island International Airport is located in the northeast side of the island next to a lagoon and a lowland isthmus separating the island from the peninsula of Lazareta. Skiathos Airport is served by Olympic Air flights from both Athens and Thessaloniki, while foreign airlines provide charter flights from a range of airports from European countries such as the UK, France, Germany, 
The Netherlands, Italy and Cyprus. Skiathos is an international tourist destination; the total tourism capacity is approximately 15,000 beds.

\subsection{Skopelos}

In Skopelos, tourist development started after 1990s. The economy of Skopelos is now fully dependent on the tourism industry which supports construction and other development parts. Skopelos is also a year round retirement destination for Northern Europeans. Some residents expected an increase in tourism due to the filming of Mamma Mia! on the island in September 2007.

Tourism development in the island has intensified since the early 1990s. There are 47 hotels which have a total of 2,455 bedrooms and an overall total of 4,870 beds. Regarding quality of tourism services, there are 5 four-star hotels and 9 three-star hotels while the majority of the hotels is in the lower division, moreover the quality of accommodation is high since most hotels were constructed after 1990. It is worth noting that many tour operators have registered their hotels at low categories for tax purposes. The tourist season ranges from late May to September.

Table 3: $\quad$ Total passengers in Skopelos, Allonisos and Skyros ports.

\begin{tabular}{|l|c|c|c|c|}
\hline & Skopelos town port & Skopelos, Glossa port & Allonisos & Skyros \\
\hline 2009 & 134,586 & 42,780 & 62,260 & 78,049 \\
\hline
\end{tabular}

\subsection{Allonisos}

Alonisos is a very quiet little island, located close to the east of Skopelos. It is primarily a destination for day trippers from the nearby islands, as a short vacation, for people who might want to escape from massive tourism destinations. Total tourism capacity is approximately 3,500 beds.

\subsection{Skyros}

The island is famous for its many natural beauties and traditional customs. This combination, along with low but quality tourism makes Skyros have selective visitors, thus retaining its traditional character. The civil airport of the island has one administrator; the Airport Manager. In 2010, there were no charter flights abroad. In 2008 and 2009, a limited number of Dutch people visited the island by charter (see Table 4). Domestic flights connect Skyros to Athens and

Table 4: $\quad$ Skyros airport statistics.

\begin{tabular}{|c|c|c|}
\hline \multicolumn{3}{|c|}{ SKYROS AIRPORT 1 } \\
\hline & \multicolumn{3}{|c|}{ DOMESTIC } \\
\hline YEAR & 4.368 & 4.460 \\
\hline 2008 & 4.611 & 4.799 \\
\hline 2009 & 916 & ABROAD \\
\hline & 866 & 1.019 \\
\hline 2008 & \multicolumn{2}{|c|}{} \\
\hline 2009 & \multicolumn{2}{|c|}{} \\
\hline
\end{tabular}


Thessaloniki. In 2009, 84,232 visitors visited the island of Skyros from Evia, arriving by boat. Specifically during June to July and August 41,071 passengers arrived on the island. The total tourism capacity is approximately 1650 beds.

\subsection{Old Trickeri}

The island's only village is called Trikeri and it has a few taverns, a mini market and a few beds in the hospitality lodgings. The island is simple and so beautiful; the village by definition is quiet and the locals are very hospitable.

\section{Environmental indexes}

The coast and its adjacent areas, on and off shore, is an important part of a local ecosystem as the mixture of fresh water and salt water in estuaries provides many nutrients for marine life. Salt marshes and beaches also support a diversity of plants, animals, and insects crucial to the food chain. The need of indicators of sustainable development to assist in assessing and evaluating sustainability has been expressed in various studies [2-4]. Since 1980, the idea of sustainable development was established in policy and academic circles to discuss the combination of development and the environment. Now, after 20 years, the environmental indicators can analyze the environmental condition of tourism destinations. In this study, we present indicators about the pressures on the environment as tourist development indexes: waste management, illegal buildings, shore and marine pollution, fresh water resources quality and tourism development is adding to already existing pressures in coastal areas and population densities are increasing in tourism coastal regions during seasonal peaks $[2,3]$.

Table 5: $\quad$ Beach impact factor and beds per kilometers.

\begin{tabular}{|l|c|c|c|c|c|}
\hline Table 6: & $\begin{array}{c}\text { Beaches } \\
\text { length }(\mathrm{km})\end{array}$ & $\begin{array}{c}\text { Total seasonal } \\
\text { population }\end{array}$ & $\begin{array}{c}\text { Total tourism } \\
\text { capacity }\end{array}$ & $\begin{array}{c}\text { Beds/km } \\
\text { of beach }\end{array}$ & $\begin{array}{c}\text { Beds/area sq } \\
\mathrm{km}\end{array}$ \\
\hline ALLONISOS & 16.67 & 6142 & 3442 & 206.4 & 26.55 \\
\hline SKIATHOS & 13.1 & 20,722 & 14,562 & 1111.6 & 291.8 \\
\hline SKOPELOS & 14.55 & 12,210 & 7514 & 516.4 & 78.02 \\
\hline TRIKERI & 0.2 & 148 & 61 & 305 & 24.4 \\
\hline SKYROS & 16.45 & 4248 & 1646 & 100.06 & 7.37 \\
\hline
\end{tabular}

With this indicator we analyze the pressures facing the coastal environment, describing the concentration of people visiting and using the facilities of the coastal area, and especially the beaches. From the data presented in Table 5, Skiathos has the most serious pressures concentrated at the coast and does not face the same pressure as the other islands. 
Urban waste management (solid and liquid) in Sporades is characterized by lack of efficiency regarding waste treatment in the small cities and villages. Only the large urban centres fulfil the basic requirements of modern waste management installations. It is interesting to note that other smaller settlements do not even have a complete urban waste collection network.

Urban waste management (solid and liquid) on all the islands except Skiathos is characterized by lack of efficiency.

In table 7 we present the relationship between illegal building incidents. The data presented in Table 7 indicate that Skiathos highlights serious coastal pressures on the coastline.

Table 7: Waste management.

\begin{tabular}{|l|c|c|c|}
\hline & $\begin{array}{c}\text { Urban waste } \\
\text { management }\end{array}$ & $\begin{array}{c}\text { Waste (garbage } \\
\text { management) }\end{array}$ & Noise nuisance \\
\hline ALLONISOS & 0 & LS & 0 \\
\hline SKITATHOS & $90 \%$ & LS & 1 \\
\hline SKOPELOS & $70 \%$ & NLS & 1 \\
\hline TRIKERI & 0 & LS & 0 \\
\hline SKYROS & UC & LS & 1 \\
\hline
\end{tabular}

UC: under construction; LS: Landfill sites for municipal waste; RLS: Landifill sites for residual municipal waste (after recycling); NLS: Landfill sites for municipal waste non attending to 1999/31/EU; IS: Illegal sites for municipal waste.

Table 8: $\quad$ Illegal building and dumping incidents.

\begin{tabular}{|l|c|c|c|c|c|}
\hline & $\begin{array}{c}\text { Illegal } \\
\text { buildings }\end{array}$ & $\begin{array}{c}\text { Hotels' urban } \\
\text { waste }\end{array}$ & Other & Ships/shipwrecks & $\begin{array}{c}\text { Ships'/oil } \\
\text { residuals }\end{array}$ \\
\hline $\begin{array}{l}\text { SKIATHOS } \\
\text { 1995-2008 }\end{array}$ & 7 & 7 & 2 & 7 & 4 \\
\hline $\begin{array}{l}\text { SKOPELOS } \\
\text { 1996-2008 }\end{array}$ & & & & & 1 \\
\hline
\end{tabular}

\section{Tourism impacts}

Tourism can generate both positive and environmental impacts depending on how well development is planned and controlled. The principal impacts are outlined below. (Impacts of tourism in coastal areas are: urban tourism enterprises, improper solid waste and garbage treatment, reduction of water resources, and loss of free space in the towns [7].)

\subsection{Negative impacts}

Negative impacts are water pollution, air pollution, noise pollution, visual pollution, overcrowding and congestion, land use problems, environmental hazards, landslides, flooding and sedimentation of rivers, damage to historic and archaeological sites, and improper waste disposal. 


\subsection{Positive impacts}

Positive impacts are the conservation of important natural areas, conservation of important historic sites, improvement of environmental quality, enhancement of the environment and infrastructural improvement. Tourism carrying capacity assessment is the most important analytical technique to estimate the environmental pressures of uncontrollable tourist development.

\section{Potential tourism development in Northern Sporades islands}

In order to approach the potential of this specific destination we have to first process the local, national and international tourism trends that obviously have considerable impact. The current economic situation, together with the geographical, environmental and sociocultural status of the region create an important framework that has to be seriously considered in this regard. Briefly, we must point out the following conclusions.

- The islands seem still unspoiled from mass tourism; they have serious and valuable assets in natural and environmental resources.

- Despite the attractiveness and sociocultural purity continuing to exist, the following issues are crucial.

- Transportation by sea and by air is definitely playing a decisive role to the future development of the destination.

- Skyros has a small airport just for domestic routes and Skiathos has a bigger one but it is not well organized for international flights - there are only 110,000 international arrivals per year (see Table 2). Sea transportation is more important at the moment as thousands of people reach the islands by ship.

- Considering that Anchialos airport (close to Volos town) has boomed lately attracting mostly low cost carriers, there must be more careful planning for the boat connections via Volos or elsewhere. A good solution is access through the small airport of Anchialos by the use of Almyros port. This way will be an interesting getaway to connect quickly those arriving to the airport with Old Trikeri Island, Skiathos Skopelos and Allonissos.

- Finally, it is matter of strategic planning in order to balance the demand, and be well organized in providing the tourism product and maintaining the level of well being of the locals.

There are numerous examples where such attractive island destinations maximized their visitation and revenues by just growing the quantity of their product without any balanced approach. Obviously, local community and natural 
resources receive pressure and slowly they lose their competitive advantages which initially were supporting the attractiveness of their destination.

\section{Proposals}

Tourist development depends on the quality of the environment and the special characteristics that may attract visitors to the area. It has been proven, beyond any doubt, that in the long term, uncontrolled development has serious impacts on the natural and build environment.

Environmental indictors show that the transformation from a low quality, high-number (mass) tourist trade to an alternative trade of high quality is not easy, especially when basic infrastructure units, such as waste management systems, town planning policies and building practices, government incentives etc. are lacking. It is a well known fact that such inadequacies have serious environmental consequences, and hinder any attempts towards developing a high quality tourist industry.

The increasing public interest in nature and landscape preservation is, today, considered to be a major positive factor in the tourist development process. It is also well known, however, that the growing influx of visitors can exert strong pressures on fragile ecosystems. Many proposals have been put forward to eliminate these side effects, and the concept of protected areas, such as national parks and reserves, are now an integral part of nature based tourism [2]. Serious attempts have to be made to ensure the development of a high quality tourist trade, based on alternative tourist products and services, mitigating environmental consequences.

\section{References}

[1] www.ypa.gr

[2] Briassouls H., Policy and Practice, Sustainable Development and its Indicators: through a (planner's) Glass Darkly, Journal of Environmental planning and management vol. 44(3), 409-427, 2001.

[3] Stein I., Riley J., Halberg N., Issues of scale for environmental indicators, Agriculture, Ecosystems and Environment vol. 87, 215-232, 2001.

[4] Petrosillo I., De Marco A., Botta S., Comoglio C., EMAS in local authorities: Suitable indicators in adopting environmental management systems, Ecological Indicators, Elsevier vol. 10.1016, ecoind., 2011.

[5] Trumbic I, Tourism carrying capacity assessment in the Mediterranean Coastal Tourist Destinations, 14 Biennial Coastal Zone Conference, New Orleans Louisiana, July 2005.

[6] http://en.wikipedia.org/wiki/Coastal zone\#cite note-0 11-12-10

[7] Lickorich L., Jenkins C., An Introduction to Tourism, Butterworth Heinemann, Oxford 2000. 
[8] Fidelis T, "Integrating environmental issues into the Portuguese planning system - 10 years of emerging challenges and persistent problems" Conference on Sustainable Planning and Development, Bologna 2005, Wessex Institute of Technology. 